Marcin MENKES

Warsaw School of Economics

\title{
Cooperation Between the European Union and International Organisations in the Field of Commercial Policy
}

\section{Introduction}

Progressive institutionalisation of the European Community "finds itself caught between two opposing tendencies"2. The constitutional principle of subsidiarity and national short-sightedness hinder integration processes. On the contrary, mechanisms of globalization result in a "world-wide integration", preventing small actors from being heard at the international stage or from participation in share of wealth. The only way to preserve the privilege of enjoying the world's highest living-standards and the hope of fighting world's poverty is to adjust to requirements of the global economy ${ }^{3}$. Either the EC/EU, together with its Member States, learn how to cooperate with ever more expansive international organisations, or its own voice will gradually lose any magnitude.

In the paper I analyse certain problems of the EC cooperation with international institutions. I focus upon cooperation based upon fix institutional structures. As the latter only occasionally poses international legal personality, the said cooperation exceptionally amounts to a membership in an international organisation.

First I analyse difficulties which the European Community face while following accession procedures to external institutional structures. In the second part I scrutinize some aspects of the on-going cooperation. In the end I highlight consequences of the EC non-membership in such struc-

1 The Common Commercial Policy, the first pillar of the EU, will be referred to as the Economic Community, EC.

2 J. Sack, The European Community's Membership of International Organisations, "Common Market Law Review" 1995, no. 32.

3 H. Mahony, Europe is increasingly fading away, "EUobserver", 30 March 2007. 
tures, both for the organisation itself and for its Member States, and some consequences of the discussed constitutional reform.

\section{Difficulties of accession to an international organisation}

\subsection{Constitutional restraints}

Membership in international organisation may take place in two ways. Either by participation in conclusion of an international organisation constitutional treaty (original membership), or subsequently, if allowed by the treaty, by following the accession procedure (derivative membership) 4 .

The European Community is no exception to the rule ${ }^{5}$. Its capacity of concluding agreements with third countries has been first generally acknowledged in the European Agreement on Road Transport judgment ${ }^{6}$. The European Court of Justice recognized then that the capacity of establishing contractual links with third states arises not only from the express treaty provisions, but also from other provisions as well as from measures adopted within their framework by the Community institutions. Six years later the Court expressly recognized the EC's capacity of becoming a founding-member of another international organisation. In the Opinion on the 'Draft Agreement establishing a European laying-up fund for inland waterway vessels ${ }^{, 7}$ the Court acknowledged the EC's authority to enter into international commitments necessary for the attainment of specific objectives, whenever the Community law has already created Community

4 International organisation membership capacity, as an element of capacity of maintaining international relations, is sometimes described as a constituent of international legal personality. See: J. Menkes A. Wasilkowski, Organizacje Międzynarodowe. Prawo instytucjonalne (International Organisations. Institutional Law), Warszawa 2006, p. 97. See also: A. G. Toth, The Oxford Encyclopedia of the European Community Law. Institutional law, Oxford 1990, Legal Personality of the European Community (p. 351) and External relations (p. 256).

5 I. Govaere, J. Capiau, A. Vermeersch, In-Between Seats: The Participation of the European Union in International Organisations, "European Foreign Affairs Review" 2004, no. 9.

6 C 22-70, Commission of the European Communities $v$ Council of the European Communities. European Agreement on Road Transport, [1971] ECR 263.

7 Opinion 1/76, Draft Agreement on the establishment of a European Laying-up Fund for Inland Waterway Vessels, [1976] ECR 1279. 
powers within its internal system, even in the absence of express provisions in that connection. In particular the ECJ recognized the right to "set up an international organism, to give the latter appropriate powers of decision and to define $[\ldots]$ the nature, elaboration, implementation and effects of the provisions to be adopted within such a framework". Currently Article 300(3) of the Treaty establishing the European Community (TEC) provides legal basis to conclude "agreements establishing a specific institutional framework by organizing cooperation procedures". The said article does not, however, directly refer to a different accession procedure to an already existing organisation. Consequently it may be applied only by analogy, which poses considerable practical problems ${ }^{8}$. In particular, on the grounds of public international law, a capacity to conclude treaties by the $\mathrm{EC}$, does not amount yet, from the internal (Community) perspective, to right of acceding another international organisations?

Also particularities of the Community legal status affect possibilities of membership of the Community in other institutional structures. Even though legal personality of international organisations as such does not raise concerns ${ }^{10}$, it's extend is somewhat problematic ${ }^{11}$. This in turn influences the capacity of establishing inter-institutional relations.

The legal capacity of international organisations, defined on the grounds of organisations' functions and powers, is not easily distinguished from the legal personality ${ }^{12}$. In particular it is not clear, whether the legal

${ }^{8}$ More: see supra note 4, p. 157.

9 R. Frid, The European Economic Community. A member of a specialized agency of the United Nations, "European Journal of International Law" 1993, vol. 4, no. 2.

${ }_{10}$ Reparation for Injuries Suffered in the Service of the United Nations ([1946] ICJ Rep 174); also: L. Oppenheim "International Law", $1996,9^{\text {th }}$ edition. Although there is a general agreement that international organisations can posses legal personality, their fundamental features raise serious concerns, just to mention legal basis of personality (either expressly on the basis of organisation's statute or impliedly in consequence of obtaining autonomy); more: supra note 3, p. 137-145.

${ }^{11}$ E. Steinberger, The WTO Treaty as a Mixed Agreement: Problems with the EC's and the EC Member States' Membership of the WTO, EJIL 2006, vol. 17, no. 4.

12 The wording of constitutional treaties of international organisations results only in greater confusion in that respect, as they freely use different terms without defining them properly. The UN Charter refers to pusposes, functions and powers (Fr: buts, fonctions et pouvoirs); the EC Treaty about organisation's tasks (Fr. mission); the WHO Constitution distinguishes the objective from functions (Fr: le but, les fonctions); the UNESCO Constitution speaks of purposes and functions of the organisation as opposed to the functions ot its organs (Fr: buts et fonctions, les fonctions). Al- 
personality of international organisations is limited by their competences; or rather the personality per se is unlimited, as opposed to organisation's attributed powers. If the legal personality was restricted by organisation's functions, in which case the legal personality would be identical to the capacity to incur the legal responsibility, then also the possibility to hold the organisation legally responsible is limited. That is, what the International Court of Justice's asserted in the Advisory Opinion on Reparation for Injuries suffered in the service of the United Nations ${ }^{13}$. Accordingly the $\mathrm{EC}^{14}$, as any other international organisation, would be incapable of undertaking external actions outside the scope of its capacity, since the subject existing only within the limits of its competences cannot exceed them. In particular an accession to any institutional framework, whose functions are defined broader than those of the European Community, would be impossible. If accept unrestricted character of international organisations' legal personality, the latter can be held responsible also for ultra vires acts similarly to states. This is what the International Law Commission suggests in its works on responsibility of international organisations ${ }^{15}$. Answer to those questions is fundamental for the possibility of accession to each particular international institution; it shapes membership rights and ways of realising membership benefits. The extent to which a membership in an external institutional structures can influence the European Community itself, can be seen in the EJC's opinion on 'Draft agreement between the Community, on the one hand, and the countries of the European Free Trade Association, on the other, relating to the creation of the European Economic Area" "16. The Court acknowledged there that the Community

ternate use of those terms contradicts the principle of language rationality, providing for distinct meaning of different notions. As a result distinction between the motivation for cooperation, stipulated results, afforded means of action and their results seem to evaporate.

${ }_{13}$ Reparation for injuries suffered in the service of the United Nations, Advisory Opinion: ICJ Reports 1949, p. 174.

${ }_{14}$ The legal personality of the EC is founded upon by art. 281 TEC, criticized for its curtness while compared to its predecessor - art. 6 of the Treaty establishing the European Coal and Steal Community. See: supra note 3 p. 143.

15 M. Menkes, Odpowiedzialność organizacji międzynarodowych w pracach Komisji Prawa Międzynarodowego (Responsibility of international organisations in works of International Law Commission), "Warsaw University Law Review" 2007, vol. 1.

${ }^{16}$ Opinion 1/92, Draft agreement between the Community, on the one hand, and the countries of the European Free Trade Association, on the other, relating to the creation of the European Economic Area, [1992] ECR I-2821. 
competence to conclude international agreements "necessarily implies that the Community may accept rules made by virtue of an agreement as to the sharing of the respective competences of the Contracting Parties". Consequently, although powers conferred upon the Community's institutions can be modified pursuant only the TEC procedures, "an international agreement concluded by the Community may confer new powers on the Court, such as the power to interpret the provisions of such agreement, provided that in so doing it does not change the nature of the function of the Court as conceived in the EEC Treaty". Still the interpretative freedom concerning interinstitutional cooperation of the European Community is restricted to "only those powers which have been conferred upon it"17.

\subsection{Limitations of legal personality}

The European Community's legal capacity is bound by the principle of attributed powers (art. 5 TEC). In terms of external relations only few provisions, however, confer competences upon it ${ }^{18}$. There is no general clause of competences alike art. 24 of the Treaty on European Union (TEU) ${ }^{19}$. The restrictive effect of art. 5 TEC was fully exposed in the ECJ Opinion $2 / 94^{20}$. The Court stated that article 308 , authorising actions where the Treaty "has not provided necessary powers", does not cover activities in areas not included among objectives of the Community (articles 2-4 TEC). It is sometimes difficult to delimit in practice the accurate scope of competences and to distinguish exclusive powers of the EC from competences concurrent/coexistent and shared with the EC Member States ${ }^{21}$. Furthermore it is an ever-changing, dynamic image, as the competences

17 Opinion 2/94, Accession by the Communities to the Convention for the Protection of Human Rights and Fundamental Freedoms, [1996] ECR I-1759.

18 Art. 133 TEC on common commercial policy; art. 310 TEC on association agreements; art. 310 TEC on competition; art. 181 TEC on development cooperation; art. 174 TEC concerning the environmental protection and art. 181a TEC on economic, financial and technical cooperation.

19 EU on the other hand has not been expressly granted legal personality.

20 See supra note 4. According to ECJ even though respect for human rights and fundamental freedoms remains a precondition for legality of community legal order, protection of those rights as such does not belong to the organisation's objectives.

21 C. D. Ehlermann, Mixed Agreements. A list of Problems, in: Mixed Agreements, edited by D. O'Keeffe, H. G. Schemers, Deventer 1983. 
can be transferred upon the Community expressly by Member States, by application of the doctrine of implied powers on the basis of the ERTA judgement (a safeguard for the effet utile of EC law ${ }^{22}$ ), or where such a transfer would be "indispensable for the achievement of the internal objectives of the Community" accordingly to the Opinion $1 / 76^{23}$. As a result EC's partners face two phenomenon. On the one hand they witness an internal transfer of competences, on the other an evolution of the Community capacity to conclude international agreements ${ }^{24}$.

If, due to internal division of powers, the Community becomes a member of an institutional structure along with its Members States, on the basis of a mixed agreement, such cooperation may result in widening of EC's own capacity of concluding international agreements. This will occur, if the mixed agreement in question consists of one agreement between the EC and its partner and another between the Community and its Member States on the basis of which the latter transfer necessary powers upon the EC. The same will happen, if the mixed agreement consists of two parallel agreements between the EC and its Member States on the one side and other partner on the other. If such an agreement binds entirely the Community, then its Member States may decide whether to transfer or share the necessary powers with the organisation. If the EC becomes a party only to some part of the agreement, its ius tractatuum remains unaltered. The last option is the least favourable to third-partners, however ${ }^{25}$.

Another consequence of limited legal capacity of the EC are mixed negotiations. For the same reason the European Community cannot become a full member of any international agreement, it cannot alone negotiate agreements, on the grounds of which it will become a member of institutional structures together with its Member States. As a result the course of negotiations depends on three factors. Composition of a European delegation, division of powers between the Community and its Member States and the principle of the Community solidarity. To composition will vary

22 ERTA, Draft Agreement of the establishment of a European Laying-up Fund for Inland Waterway Vessels ([1977] ECR 741).

23 See also: supra note 10, p. 848.

24 A. Cieśliński, Kompetencje Wspólnoty Europejskiej do zawierania umów międzynarodowych $w$ świetle orzecznictwa Europejskiego Trybunału Sprawiedliwości, in: Wspólnoty Europejskie (Unia). Wybrane problemy prawne, cz. II, ed. J. Kolasa, Wrocław 1998.

25 A. Bleckman, The Mixed Agreements of the EE in the Public International Law, in: "Mixed Agreements", supra note p. 155. 
from a single European delegation taking part in bilateral negotiations, to more complex rules of composition of delegations for multilateral negotiations $^{26}$.

Supposing that the very accession/membership is legally possible, the question of representation raises subsequent problems. Depending on whether the particular act falls within the scope of competences of the EC, the EU or the Member States, accordingly the Commission (art. 300-304 TEC), the Presidency (art. 18 TEU), national governments or combination of those actors will be entitled to act in foro externo ${ }^{27}$. Such system happens to provoke intense quarrels among those concerned (discussed further in par. 4).

\subsection{Policy obstacles}

Alongside above concerns two factors merit consideration: internal relations with the EC Members States and partner-organisations reluctance.

As for the former, one shall not forget that the external policy, including membership in international organisations, has been traditionally perceived by States as an integral part of sovereignty. Similarly the EC Member States are reluctant when it comes to transfer competences in that $\operatorname{area}^{28}$, on the one hand willing to increase importance of the European voice at international forum by acting outside together, on the other hand, afraid of losing "national identity" "29, or at least of diminishing their own political presence. It takes a hard step-by-step process to obtain each concession, as European States remain unwilling to rescind their international

26 A single European delegation consists of the European Commission and Member States representatives; representative of the state of Presidency takes the chair of the delegation. The EC may also send its own delegation separate from national delegations. Also there are several mixed models. For instance including representatives of all Member States in the EC delegation or one representative of the State of Presidency (this is the practice at the UN General Assembly forum); since the 1967 GATT negotiations Kennedy Round the EC together with its Member States do also send a common delegation. J. Groux, Mixed Negotiations, w: Mixed Agreements, supra przypis.

27 More: see supra note 4; also J. Groux, Mixed Negotiations, in: supra note 17.

28 A. Wasilkowski, Suwerenność w prawie międzynarodowym i prawie Europejskim (Sovereignty in international and European law), in: Prawo Międzynarodowe Publiczne a prawo Europejskie. Konferencja Katedr Prawa Międzynarodowego w Karpaczu; 15-18 Maja 2002, eds. J. Kolasa, A. Kozłowski, Uniwersytet Wrocławski.

29 See supra note 17. 
presence for the benefit of the Community. That is the main reason behind the parallel membership of all 27 European States in the WTO in their own rights.

Referring to the latter restraint, the Community may also be incapable of becoming a member of an institutional structure due to its constitutional restraints. Among other doubts, such a membership raises question about equality of the Members States, since usually States belonging to the "acceding organisation" (here the EC), are already members of the other organisation. Consequently membership of the EC amounts to double membership of European countries ("directly" and "through the Community"). To prevent that happening, some international organisations are opened for states only ${ }^{30}$. This leaves the EC no other choice than accepting an observer status (as it did in the International Labour Organisation), and purely advisory role. This might be particularly problematic in terms of Community internal legal order, if the subject matter of such organisation belongs to Community exclusive competences, in which case the EC operates "through the medium of the Member States"31.

Also reluctance of third States may hinder cooperation. Imprecise legal nature of the EC and ever-evolving nature of internal division of powers leaves third parties in a situation of uncertainty ${ }^{32}$, as to who is competent to act in particular situation, or who would be responsible for breaches of international obligations - especially in case of mixed agreements ${ }^{33}$. Also the very exercise of membership rights may be a reason for considerable

30 In such situation it is a question of good will of other parties, whether to enable accession of the EC. For instance the Food and Agricultural Organisation (FAO) amended its Constitution and General Rules in 1991 (see: paragraphs $376-379$ of the Report of the twenty-sixth Conference of FAO, Rome, 9-27 July 1991, X5587/E), allowing accession of "regional economic integration organisations".

31 Opinion 2/91, Convention No 170 of the International Labour Organisation concerning safety in the use of chemical work ([1993] ECR I-061).

32 Having that on mind, the ECJ stated that despite transfer of competences upon the Community, which took place during ERTA case proceedings (supra note 18), a sudden change of negotiators, by exclusion of European States delegations, at such late stage of negotiations would endanger conclusion of the treaty, therefore the Member States retained their presence in the course of negotiations "in the name of the European Union". More: see supra note 4, p. 173-174.

33 On the other hand it happens sometimes that those are third States who insist on the accession of the EC Member States, alongside the Community, as they are not convinced about possibility of executing their rights against the Community (as it occurred with the African, Caribbean and Pacific ACP States). 
uncertainty. Complexity of problems arising at that stage may be seen on the example of the EC membership in the WTO, which relates to exclusive, concurrent and coexistent competences of the Community ${ }^{34}$.

\section{Membership hurdles}

\subsection{Voting rights}

A successful finishing of accession procedure does not solve yet all the difficulties. For instance voting rights. Shall the Community be given an extra voting competence in its own right, separately from its Member States $^{35}$, according to the principle of equality of members, or rather shall it vote instead of the Community Members States, according to the, preventing over-representation, principle of neutrality which. What shall be the power of such vote - cumulative right consisting of all previously possessed by the EC states or rather only one vote ${ }^{36}$.

\subsection{Alternate exercise of the membership rights}

As provided by the FAO's Constitution (CFAO) ${ }^{37}$, although membership of "regional economic integration organisations" (REIO) is accessory to membership of respective Member States, REIOSs are entitled to exer-

34 In LAN case (LAN Case, Customs Classification of certain computer equipment (Panel Reports WT/DS62/R,WT/D67/R I WT/D68/R of $5^{\text {th }}$ February 1998) it wasn't even clear, who shall be a party to the proceedings - only the Community or the Member States or a joined representation. Unfortunately none of the WTO dispute settlement organs wanted to give express answer upon this questions, and the sentence is perceived as rather averting from doing so, than clarifying the issue. More: see supra note 10 .

35 As it is the case under art. 10(3)(a) and 14(b) of the Protocol of the Madrid Agreement concerning Registration of Marks of 27.06.1989 (http://www.wipo.int/madrid/en/legal_texts/trtdocs_wo015.html).

36 For instance as provide art. XII (3) and (4) of the Canberra Agreement of 20.05.1980 on the conservation of Antarctic marine living resources ([1982] Australian Treaty Series No. 9).

37 Art. II (4), (8),(9) and (10) of the CFAO (http://www.fao.org/DOC$\mathrm{REP} / 003 / \mathrm{X} 8700 \mathrm{E} / \mathrm{x} 8700 \mathrm{e} 00 . \mathrm{htm})$. 
cise their rights, in the field of exclusive competences, on its own behalf, independently of their Member States ${ }^{38}$. Two competence declarations are necessary, however ${ }^{39}$. First, a general declaration to finalise accession procedure $^{40}$. Such declaration is complemented by specific statements on every item of the agenda at each FAO meeting. If no statement is made, competence is presumed to lie with the Member States ${ }^{41}$.

As a result an overwhelming amount of administrative paper work is necessary, due to fears both of the EC States, not to create a precedent to be used outside the FAO, and third parties, of exercising double member$\operatorname{ship}^{42}$. This may result in disputes despite meritorical consensus between parties, as shows the following example.

In field of shared competence the exercise of the voting right depends on the adoption of a Common Position. If none was established the Member States vote at their will. If a Common Position has been settled then, depending on who is competent in the matter to be voted upon, either the Commission or the Member States will cast the vote. Soon after the EC accession to the FAO fisheries agreements were negotiated. The original scope of negotiations was qualified as a "shared competence" area ${ }^{43}$. The Commission and the Council reached an agreement establishing the Common Position. The question was who shall cast the vote. The Commission argued that the actual subject matter of the agreement lied within Community functions, so it was in the right. The Council disagreed. In the end the Member States casted votes. Subsequently the Commission brought an ac-

38 Accession of the EC to the FAO was a mile step in terms of international institutional law for at least two reasons. Firstly, due to the growing consent from that moment onwards, even though such situation did in fact "in smaller scale" occur also before, for international organisations membership in other organisations. Secondly, for the first time the EC was permitted into the UN family. Since all the UN specialized organisations are based upon same principles, numerous countries, afraid of setting a precedent, were very reluctant to let that happen. More: see supra note 6.

39 Similar procedure was introduced for the EU - UNCTAD cooperation. There however, due to a "lower significance" of common statements, which does not raise fears concerning precedents to be followed under other institutional frameworks, the specific declarations are made only if necessary.

40 Art. LXI(2) of the rules of procedure of the FAO.

41 Art. II (6) CFAO.

42 More: see supra note 1.

43 As a matter of fact, despite original ambitions, provisions on flagging, area of the exclusive competence of the Member States, were not included in the final agreement. Legal classification of the agreement, however, was not changed. 
tion for annulment before the $\mathrm{ECJ}^{44}$. The Advocate General Jacobs ${ }^{45}$ dismissed the case as an inadmissible "non-issue", as there was no true disagreement between the parties, particularly having in mind that both the Commission and the Member States are bound by Common Positions. The Court, however, did not agree with that opinion. The ECJ stated that question of exercise of voting right is not of the procedural character, but touches upon the very essence of membership rights. Furthermore such a depreciating attitude could lead in a long-term to waste of the hard-won benefits of the EC membership in the $\mathrm{FAO}^{46}$.

The UN Convention on the Law of the Sea provides yet another example of difficulties made to the $\mathrm{EC}$, without clear legal ratio legis. On the grounds of art. 4(3) of the annex IX, the EC exercises its voting rights, according to internal its internal division of powers, only in the presence of representatives of the Members States. Such obstacle, concerning the field of the EC exclusive competences, seems unjustified.

\subsection{Finances}

Also particularities of the EC legal character may result in widening of some of its membership rights. On the basis of art. XVIII (2) CFAO, Member Nations ${ }^{47}$ and Associated Members are obliged to different fiscal contributions. Furthermore, Member Organisations are expected to cover only membership administrative costs (art. XII (6) CFAO). They are not entitled to take vote on the budget at conferences, however. This can be explained by the fact that membership of a REIO is only possible, if majority of its members are also FAO members, thus obliging the REIO to pay entire membership fee would double the fiscal burden carried by those States. Since REIOs almost do not contribute to the FAO's budget, they

44 C-25/94, Commission v. Council ([1996] ECR I-1469).

45 Ibidem.

46 While focusing on the manner of exercising membership rights by the European States, cooperation with the Security Council of the UN and the Organisation for Security and Co-operation in Europe (OSCE) is worth recalling. Whenever a national representative of the EU Presidency State takes the floor, he does so in the name of the entire EU. In the OSCE a there is also known a customary right of the EU Presidency-country representative to use a "Presidency" plate. K. Wolfke, Practice of International Organisations, "The Polish yearbook of international law" 1966/67, p. 183-194.

47 The notion of "member nations" was used in the original treaty, which also indicated that in order to allow EC membership it was necessary to amend the Constitution. 
are also not entitled to vote in relevant matters ${ }^{48}$. This may cause problems in case of self-financing, autonomous REIOs. To some extent the EC is already in such situation; accordingly the Community shall rather cover entire membership fee and enjoy all privileges ${ }^{49}$.

Surprisingly it is a one-way logic. For instance the European Court of Justice, advisory opinion $1 / 94^{50}$, stated that financial contributions of the EC Members States do not justify per se their participation in the conclusion of the WTO Agreement ${ }^{51}$.

\subsection{Protecting Community autonomy}

Just as fearful of deprivation of their sovereignty States are reluctant to transfer competences on the EC, the European Community tends to secure its hardly-attained autonomy. This is particularly true while considering accession to another institution, whose functions are parallel to those of the EC. In such situation the Community may want, on the one hand, to secure safety of its legal order, on the other hand, to prevent possible collisions between two systems. Such were the arguments concerning accession of the EC to the European Patent Convention (EPC).

The ratio legis of intellectual property rights harmonisation was to secure creation of the single European market by preventing creation of monopolies over products and technologies interfering with the free movement of goods, which in turn would undermine the EC competition law policy. Despite numerous legislative activities ${ }^{52}$, the Community still did not manage to harmonise entire IP law. For instance in terms of patent law, measure simplifying administrative procedures have been undertaken, however, no EU patent as such exists ${ }^{53}$. In order to enhance eco-

48 Budgetary negotiations are at the same time policy discussions, hence exclusion from decision making process in those matters is more significant then it could seem. See supra note 6.

49 More: see supra note 6, p. 252.

50 Opinion 1/94, Competence of the Community to conclude international agreements concerning services and protection of intellectual property, [1994] ECR I-5267.

51 More: Jacques H. J. Bourgeois, The EC in the WTO and the Advisory Opinion 1/94: An Echternach Procession, 32 CML Rev (1995).

52 E.g. Directive 92/100 - Rental and Renting Directive, Directive 93/83 - The Satellite and Cable TV Directive, Directive 93/98 - The Duration Directive.

53 The dispute over IP rights, whether to transfer this area to the EC competence or not, has been particularly vivid during WTO accession negotiations. While the EC 
nomic integration, it has been proposed to confer to the European Patent Office (EPO) the right of granting European (Community) Patent ${ }^{54}$. One of obstacles to this idea was that some parties to the EPC are not EU Members and that the Convention does not belong to the Community legal order. The Community had to ensure the compliance of the EPO organs with the acquis communautaire and to safeguard the autonomy of its legal order. That was the reason behind introduction of the Select Committee of the Administrative Council into the EPC framework ${ }^{55}$. The Committee, composed only of representatives of the EC and its Members States, is exclusively competent in Community law matters. Its objective is respect for "the relevant Community law" ${ }^{\prime 5}$. The purpose of its creation was twofold: on the one hand third states are prevented from undertaking decisions affecting acquis communautaire, on the other hand it guarantees external respect (within the EPO) for Community regulations. As a result non-EC States are bound by the EC internal regulations, thanks to adoption of parallel provisions ${ }^{57}$.

\section{Cooperation beyond institutional ties}

\subsection{Cooperation through the EU Member States}

Treaties concluded by the EC member states are not binding upon the Community, unless it is also a party to $\mathrm{it}^{58}$. The same principle applies to

Member States were willing to retain relevant functions, the ECJ, Opinion 1/94 (supra note 44), spoke in favour of joint competences necessary to conclude TRIPs Agreement. More: see supra note 47.

54 The EPO already grants European patents, which are, however, a bundle of national rights, rather than a unitary European right. Discussions on introducing a single Community patent, which have begun in 1970 s, so far have led to a stalemate.

55 According to art. 145 EPC the Committee is set up "for the purpose of supervising the activities of the special departments set up under art. 143 (2)".

56 Draft Article 149(i), EPC working paper.

57 Similar procedure has been introduced in the framework of the European Economic Area, which allowed Norway, Liechtenstein and Iceland to participate in the Common Market, without accession to the European Union itself. Relevant Community legislation, covered by the EEA Agreement, is introduced subsequently by decision of the EEA Joint Committee, consisting of respective representatives (art. 99, 100 EEA Agreement). More: see supra note 4, p. 168-170.

${ }^{58}$ In contrast the EC Member States as well as the Community institutions are bound by international obligations undertaken by the Community (art. 300(7) TEC). 
obligations undertaken by the EC States as a consequence of accession to another international institution. The question arises, however, how to qualify obligations undertaken "in the name of the Community". For instance as a result of membership in the ILO, to which the EC cannot accede. If all the EU States are members of the former organisation and functions of such organisation are covered by the field of exclusive competence of the Community, "there seems to be no convincing reason why such an international agreement [...] should not also be considered binding for the EC" ${ }^{\prime 59}$. Otherwise, in case of infringement of treaty provisions, emerges a danger of an inequitable shift of risk upon third States. Even if the Community was incapable to make its Member States fulfil their international obligations, it would be unjust to allow a de facto membership of the EC in an international organisation, in the field of exclusive EC competences, providing the Community with membership benefits without legal possibility of compelling it to fulfil its obligations. Once such responsibility is accepted, then it is up to the Community to evaluate whether possible benefits of such cooperation outweigh risks ${ }^{60}$.

\subsection{Attribution of responsibility}

Also non-membership of the Community in certain institutional structures may have far reaching consequences for its Members States. For instance the EC is not a party to the European Convention on Human Rights and Fundamental Freedoms (ECHR) and therefore it does not have locus standi in the European Court of Human Rights. Consequently a person whose conventional rights were violated has no other choice, than to sue the EC Member State(s), on territory of which the violation took place ${ }^{61}$, even if such State was not necessarily involved in the said act ${ }^{62}$ or con-

More: G. Conway, Breaches of EC Law and the International Responsibility of Member States, EJIL 2002, vol. 14, no. 3.

59 See: supra note 4, p. 176.

60 More: Fourth report on responsibility of international organisations, by G. Gaja, special rapporteur of the International Law Commission (A/CN.4/564). Also: see supra note 12.

61 "The High Contracting Parties shall secure to everyone within their jurisdiction the rights and freedoms defined in Section I of this Convention" (Art. 1 ECHR).

${ }^{62}$ In Guérin (Guérin Automobiles v. les 15 Etats de l'Union Européenne, EctHR, judgement of 4 July 2000, App. No. 62023/00) all the fifteen EU members were 
tested it ${ }^{63}$. Also it is possible that the infringement of the ECHR concerns are in which a State is not competent, or its actions were undertaken to fulfil other international obligations.

The first defence was unsuccessfully raised by the United Kingdom in the Matthews ${ }^{64}$ case, where the Court stated that the defendant was responsible for preventing a British citizen from participation in Gibraltar elections to the European Parliament, or rather not providing such opportunity, despite the previous transfer of competences in this field upon the European Community. Consequently the defendant was not relived from its responsibility on the grounds of the ECHR.

Now in Bosphorus ${ }^{65}$ case actions of Irish authorities, implementing the EC law ${ }^{66}$, were challenged as allegedly infringing fundamental right of property of the claimant. Although on the facts of the case the applicant's claim has been rejected, it was Community attitude towards human rights protection which was under inquiry rather than the State acts. The Court repeatedly stated that State actions undertaken in compliance with previous international obligations are justified, "as long as the relevant organisation is considered to protect fundamental rights [...] in a manner which

charged, even though none of them implemented questioned EU act. They were therefore held responsible for acts of the independent from Member States EC institutions (otherwise the Community wouldn't a subject of international law). More: S. Douglas-Scott, Bosphorus Hava Yollari Turizm Ve Ticaret Anonim Sirketi v. Ireland, application No. 45036/98, judgment of the European Court of Human Rights (Grand Chamber) of 30 June 2005, (2006) 42 E.H.R.R. 1, 43 CML Rev (2006).

${ }^{63}$ In Senator Lines (Senator Lines GmbH v 15 Member States of the EU, ECHR, judgement of 10 March 2004; App. No. 51717/99) the action was brought against all the Member States, even though Germany actually supported claimant's arguments in the Court of First Instance.

${ }^{64}$ Matthews v. the United Kingdom, ECtHR 1999-I (Grand Chamber); App. No. 55672/00.

${ }^{65}$ Bosphorus Hava Yollari Turizim Ve Ticaret Anonim Sirketi v. Ireland, ECtHR (Grand Chamber), judgement of 30 June 2005, App. No. 45036/98, 42 E.H.R.R.1. (2006).

${ }_{66}$ Precisely art. 8 of the Council Regulation (EEC) No. 990/93 of 23 April 1993 (O.J. 1993, L 102/14) concerning trade between the EEC and the Federal Republic of Yugoslavia, Serbia and Montenegro, which embodied previously established by the Community embargo on trade with the FRY. More: I. Conor, Can two walk together, except they be agreed? The relationship between international law and European law: the incorporation of United Nations sanctions against Yugoslavia into European Community law through the perspective of the European Court of Justice, 35 CML Rev (1998). 
can be considered at least equivalent to that for which the Convention provides" ${ }^{\prime 67}$. Otherwise a Member States can be held responsible for the Community institution acts ${ }^{68} . \mathrm{Nb}$. the Court did not consider at all the United Nations contribution towards the situation. The said Community Regulation only implemented the Security Council Resolution at the Community level, therefore merely fulfilling the EC's obligations (discussed later).

This raises another legal problem of internal, Community character. Economic sanctions - an instrument of commercial policy - fall under the first CCP pillar. As they serve non-economic purposes, however, as in the mentioned above example, they may result from non-commercial legal obligations. There is a considerable conflict potential between functions and procedures of the first and second pillar ${ }^{69}$. This just an example of impracticability of the rigid distinction between economic and political aspects of the European cooperation, which is all the more important in terms of political decisions concerning establishing cooperation with other international organisations in the CCP field ${ }^{70}$.

\subsection{The ECJ's role}

Another factor to take into account while considering coordination of distinct institutional mechanism is role of independent judicial organs. I already mentioned a situation in which common market goals may be closely related to question of human rights protection. The possible collision of those systems, Community law and the EHCR legal order, can also result from different functions of the two. In the Rutili judgement ${ }^{71}$, the ECJ acknowledged the fact that all the EEC States are also members to the ECHR and recognized the "particular role" of the convention. Since then the convention became a material source of fundamental rights, referred to as general principles of the Community law, and the rights guaranteed there became a condition of legality of Community acts. The Convention

67 A construction which has been repeated following the judgement $M$. \& Co $v$. Germany, ECtHR, App. No. 13258/87.

68 More: see supra note 64.

69 P. Eeckhout, External Relations of the European Union. Legal and Constitutional Foundations, p. 422-465.

70 S. Giller, B. Weidel, External Economic Relations and Foreign Policy in the European Union, in: S. Griller, B. Weidel (eds.), p. 5.

71 Rutili, case 36/75, Receueil, no. 14. 
did not become, however, a formal source of law. As a consequence the EC judges interpret the EHCR autonomously "within the scope of application of the Community law", in view of EC functions. Even after the Copenhagen Declaration ${ }^{72}$, confirming special role of the Convention, the risk of contrary interpretations of the Convention by both courts remains considerable.

\subsection{Supremacy of the UN Charter}

Due to internal and external obstacles the European Community cannot, at the present stage, accede to the United Nations. As for the former reason, more important from the EC perspective, UN primary field of interest concerns issues of the EU second pillar, the Common Foreign Security and Policy. Although the European Union is competent in this area, it can act only on the basis of a Common Position; not to mention concerns about Union's legal personality. Efficient participation of the organisation in the UN works would be extremely difficult upon such basis. In particularly due to the fact that if a Common Position was not established, Member States may act as they will (art. 19(2) TEU). Also the CFSP is placed only under political control of the Council (art. 11(2) TEU); excluded from the jurisdiction of the ECJ (art. 46 TEU). Inefficiency of such mechanism could have been observed during the 2003 Iraq crisis when some of the EU States, including Poland, ignored a Common Position providing for further weapon inspectors, by contribution towards measures undertaken by the USA. Also the UN is open for States only (art. 4 UN Charter) and any soon modification of the UN Charter seems very unlikely.

As UN Security Council resolutions usually concern security and foreign affairs issues ${ }^{73}$, which fall outside of the Community pillar, it is rare for the ECJ to denounce upon those matters. It happens, however, that relations between economic and security measures are inseparable - for instance economic sanctions. This might be a reason of considerable difficulties for the EC Member States. As the UN members they are obliged to carry out Security Council decisions, i.e. implement economic sanctions,

72 Declaration of the Commission of April 5, 1977, "Journal Officiel de la Communauté Éuropéenne”, no. C. 103 of April 27, 1977.

73 S. Bohr, Sanctions by the United Nations Security Council and the European Community, EJIL 1993, vol. 4, no. 2. 
which fall under the CCP pillar. The EC, exclusively competent in the first pillar, is not bound by acts of the Security Council. From the international law perspective the situation does not pose any problems, since obligations under the UN Charter prevail over others (art. 103 UN Charter). Although the EC is usually willing to cooperate, problems sometimes emerge (as in the mentioned above Bosphorus case). In Centro-Com ${ }^{74}$ case the EJC had to pronounce upon questioned Community sanction Regulation, only partially implementing original UN sanction Resolution. The Court acknowledged on that occasion that the EU Members States are bound by the UN Charter and they must undertake appropriate measures where necessary. However, if such actions concern area of the CFSP belonging to the national competences, the Member States must "respect provisions adopted by the Community" 75 . Subsequently the Court stated that if "an international agreement allows, but does not require, a Member State to adopt a measure which appears to be contrary to the Community law, the Members State must refrain from adopting such a measure" ${ }^{976}$.

\section{European Union constitutional treaties}

Two attempts of passing some form of "constitutional treaty" of the European Union failed. As it is yet unclear if Ireland, possibly also other opponents, will be asked to reconsider their decision or rather the latest treaty will be rewritten. Still having discovered that despite the latest enlargement, the EU is still capable of working; with Europe currently concerned with global financial crisis or situation in Georgia and its energetic

74 C-124/95, Centro-Com, [1997] ECR I-81.

75 Ibidem.

76 In case when UN measures were not implemented at the EU level, the ECJ acknowledged, on the grounds of art. 307 or art. 297 TEC, two scenarios. On the basis of art. 307 TEC "the rights and obligations arising from agreements concluded before 1 January 1958 or for acceding States, before the date of their accession, between one or more Member States on the one hand, and one or more third countries on the other, shall not be affected by the provision of this Treaty". It was raised on that occasion that Germany joined the UN in 1973, thus its EC Treaty obligations predate those from the UN Charter. Article 297 TEC contains an extinguishing clause "in order to carry out obligations accepted for the purpose of maintaining peace and international security". Both measures can be applied only exceptionally, however. More: see supra note 4, p. $181-182$. 
security; it does not seem as if subsequent reform attempt was to be soon undertaken. Still the project deserves attention.

First, I shall underline that even though I analyse EU international cooperation in the first pillar area, one should not believe mirage of harmony of the three-pillar temple. The European Community, even though making part of the EU institutional framework, is a separate body in terms of functions, competences and powers. Subsequent constitutional treaties refer to the entire European Union, whose foreign policy was only marginally mentioned above. Both constitutional treaties meant to erase the EC and the pillars-structure ${ }^{77}$. Despite single institutional framework the EU institution will still have different powers in different areas, however. Furthermore, although treaties are intended to simplify division of powers between the EU and its Member States, they still distinguish exclusive, shared and joined competences ${ }^{78}$. Even if Community cooperation and membership with international institutions may seem confusing in terms of Union position, the new unitary EU architecture will not clarify much.

\subsection{European Union legal personality}

As the EC is a fully-fledged international organisation, while legal personality of the UE raises serious doubts, it is sometimes suggested that the Community remained an independent organisation, while the EU constitutes rather a legal framework for coordinated cooperation ${ }^{79}$. If the reform is successful, the EU coordination mechanisms and the EC will be replaced with a new legal person - the European Union ${ }^{80}$, capable of

77 Although formally the pillar structure will be abolished, some argue that it is more a matter of semantics than actual modification Union architecture. For instance, according to the Constitutional Treaty provisions concerning external policies and action and the CCP form common Title V, Part III (The Union's external action). Different modalities concerning particular polices remain, however, unaltered and the former second pillar retains its intergovernmental character. Also the ECJ, with the exception of examining compatibility of negotiated international agreements with provisions of the Constitutional Treaty (art. III-227, par. 12), does not gain jurisdiction in this field. More: supra note 4, p. 186-188.

78 More: see http://europa.eu/constitution/index_en.htm.

79 Ch. Zacker, S. Wernicke, Prawo europejskie $w$ pytaniach i odpowiedziach, Warszawa 2000, s. 19-20.

80 Art. I-7 Constitutional Treaty. 
concluding treaties and acceding to international organisations. Some problems shall vanish, some remain (still there are no provisions concerning procedure of accession to another international organisation), some new may appear (according to the Constitutional Treaty the Minister of Foreign Affairs, competent in matters of CFSP, may encounter conflict of loyalties whilst acting as a Vice-President of the Commission.

Several concepts of legal architecture of the new European Union were discussed. Not speaking in favour of any in particular, I shall underline an important opportunity to consider. I mentioned above possibility of "appropriation" of new competences by the EC. In the area of concurrent competences this process may, however, occur in the opposite direction. Speaking of the CFSP pillar, wherever there is no Community legislation in force, the Council may shift decisions into the intergovernmental area. If former Community pillar and Union policies become a homogenous legal system, this may remove some obstacles of deepening external integration in the field of Community concurrent legislation, where there is no secondary legislation ${ }^{81}$.

\subsection{Human Rights}

As mentioned above the Common Commercial Policy regulations may be directly related to human rights protection. The situation shall change a lot after the reform. Human rights protection is to constitute one of European Union values ${ }^{82}$ and to be included among internal and external objectives ${ }^{83}$. As art. I-7(2) of the Constitutional Treaty proclaims, "The Union

81 B. Weidel, Regulation or Common Position - The Impact of the Pillar Construction on the Union's External Policy, in: External Economic Relations and Foreign Policy in the European Union, eds. S. Griller, B. Weidel, p. 23.

${ }^{82}$ Art. I-2: "The Union is founded on the values of respect for human dignity, freedom, democracy, equality, the rule of law and respect for human rights, including the rights of persons belonging to minorities. These values are common to the Member States in a society in which pluralism, non-discrimination, tolerance, justice, solidarity and equality between women and men prevail".

83 Art. I-3: "1. The Union's aim is to promote peace, its values and the well-being of its peoples. 2. The Union shall offer its citizens an area of freedom, security and justice without internal frontiers, and an internal market where competition is free and undistorted. 3. The Union shall work for the sustainable development of Europe based on balanced economic growth and price stability, a highly competitive social market economy, aiming at full employment and social progress, and a high level of protection 
shall recognise the rights, freedoms and principles set out in the Charter of Fundamental Rights which constitutes Part II of the Constitution". Also the EU will be permitted to accede to the European Convention on Human Rights $^{84}$.

\section{Conclusions}

Each stage of integration with other institutions is a new source of legal and political difficulties; starting out with accession procedures and security of the acquis communautaire up to legal problems of membership or discriminatory treatment. Yet there can be no turning-back. On the one hand the potential of globalization process as an incentive, on the other risk of marginalisation at international arena, global challenges to face and consequences as a result of non-integration as a warning. No matter which is the driving force for broader and deeper inter-institutional cooperation, the sooner Europe fully takes advantage of the opportunity the better for everyone.

\section{Streszczenie}

Autor artykułu analizuje pewne problemy dotyczące współpracy Wspólnoty Europejskiej z instytucjami międzynarodowymi. Autor koncentruje się na współpracy $\mathrm{z}$ ustalonymi strukturami instytucjonalnymi. Jako, że rzadko posiadają one międzynarodową osobowość prawną, współpraca tylko wyjątkowo obejmuje członkostwo w organizacji międzynarodowej.

and improvement of the quality of the environment. It shall promote scientific and technological advance. It shall combat social exclusion and discrimination, and shall promote social justice and protection, equality between women and men, solidarity between generations and protection of the rights of the child. It shall promote economic, social and territorial cohesion, and solidarity among Member States. It shall respect its rich cultural and linguistic diversity, and shall ensure that Europe's cultural heritage is safeguarded and enhanced. 4. In its relations with the wider world, the Union shall uphold and promote its values and interests. It shall contribute to peace, security, the sustainable development of the Earth, solidarity and mutual respect among peoples, free and fair trade, eradication of poverty and the protection of human rights, in particular the rights of the child, as well as to the strict observance and the development of international law, including respect for the principles of the United Nations Charter".

${ }^{84}$ Art. I-7(2). 
Najpierw autor analizuje trudności, wobec jakich staje Wspólnota Europejska w procesie dostosowania procedur akcesyjnych do zewnętrznych struktur instytucjonalnych. W drugiej części opracowania autor podkreśla konsekwencje braku członkostwa Wspólnoty Europejskiej w takich strukturach, dotyczące zarówno tych struktur jak i państw członkowskich UE. Omówiono także pewne skutki omawianych reform konstytucyjnych. 